\section{Experimental Calcium Silicate-Based Cement with and without Zirconium Oxide Modulates Fibroblasts Viability}

Camila Slompo ${ }^{1}$, Camila Peres-Buzalaf ${ }^{2}$, Kellen Cristina da Silva Gasque ${ }^{1}$, Carla Andreotti Damante ${ }^{3}$, Ronald Ordinola-Zapata ${ }^{4}$, Marco Antonio Hungaro Duarte ${ }^{4}$, Rodrigo Cardoso de Oliveira ${ }^{1}$

\author{
'Department of Biological \\ Sciences, Bauru School of \\ Dentistry, USP - Universidade de \\ São Paulo, Bauru, SP, Brazil \\ ${ }^{2}$ Centro de Ciências da Saúde, \\ USC - Universidade do Sagrado \\ Coração, Bauru, SP, Brazil \\ ${ }^{3}$ Department of Prosthesis and \\ Periodontology, Bauru Dental \\ School, USP - Universidade de \\ São Paulo, Bauru, SP, Brazil \\ ${ }^{4}$ Department of Dentistry, Endodontics \\ and Dental Materials, Bauru Dental \\ School, USP - Universidade de \\ São Paulo, Bauru, SP, Brazil
}

Correspondence: Rodrigo Cardoso de Oliveira, Alameda Dr. Octávio Pinheiro Brisolla, 9-75, 17012-901 Bauru, SP, Brazil. Tel: +55-14-3235-8247. e-mail: rodrigocardoso@usp.br

Keywords: cell viability, fibroblasts, zirconium oxide, MTA

\section{Introduction}

A cement to be used for endodontic purposes, both in conventional treatment, such as in surgical treatment, should be well tolerated by the periapical tissue, have dimensional stability, be easily manipulated, provide radiopacity, and effectively seal root canals (1). One of the materials used in endodontics is mineral trioxide aggregate (MTA), which was developed at Loma Linda University and has shown excellent biological properties, satisfactory physical and chemical properties, and discrete antimicrobial activity (2).

It is well known that the main component of MTA is calcium silicate-based cement. Several studies (3-5) have shown similar results for tissue response and were compared using MTA and experimental calcium silicatebased cements. However, it has been hypothesized that the arsenic present in experimental calcium silicate-based cement could be released and become harmful to the tissues. One study showed the release of arsenic was low and similar to that of MTA (4), while another study verified that neither experimental calcium silicate-based cement nor MTA presented genotoxicity (5).

One shortcoming of calcium silicate-based cement is its poor radiopacity, which precludes its radiographic visualization (6). Therefore, this material requires the addition of a radiopacifying agent.

The use of bismuth oxide (BO), which has higher porosity when associated with an experimental calcium silicatebased cement compared to calcium silicate-based cement alone (7), is commonly used as a radiopacifier, although it interferes with cement hydration (8). In addition, BO is a yellow powder, and when separated from the cement, it may turn a grayish color that can promote tooth darkening if used in coronal-pulp capping (9).

The association of other radiopacifying agents has also been studied (10), and the majority of those studies resulted in radiopacity beyond the minimum recommended by American National Standards Institute/American Dental Association (ANSI/ADA) 2000 (11), including zirconium oxide. Zirconium oxide is a biocompatible and nontoxic white powder (12). When associated with calcium silicatebased cement, it acts as an inert material and does not react with the byproducts of hydration (13).

This study verified whether the use of zirconium oxide as a radiopacifier of an experimental calcium silicate-based cement (WPCZO) would lead to cellular cytotoxicity.

\section{Material and Methods}

Tested Materials and Extract Preparation

The tested materials were white calcium silicate-based 
cement (WPC; Votoran, Cubatão, SP, Brazil), white calcium silicate-based cement with zirconium oxide (WPCZO; Votoran, Cubatão, SP, Brazil and Merck \&t Co., Inc., Whitehouse Station, NJ, USA, respectively), and white MTA angelus (MTA; Angelus, Londrina, PR, Brazil).

The association of calcium silicate-based cement and zirconium oxide was performed using a ratio of $80 \%$ white calcium silicate-based cement and 20\% radiopacifying agent by weight (8). The radiopacifying agents were subjected to analysis of particle size, and when required, the calcium silicate-based cements were sieved until the final particles measured approximately $0.062 \mathrm{~mm}$ (Bronzinox, SP, Brazil) in order to yield a more uniform particle size before mixing (8). The materials were mixed at a ratio of $1 \mathrm{~g}$ of powder per $0.3 \mathrm{~mL}$ of liquid (distilled water). The mixture obtained was added to the culture medium, Dulbecco's modified Eagle's Medium with 10\% fetal bovine serum (DMEM 10\% FBS), at an initial ratio of $10 \mathrm{mg} / \mathrm{mL}$. Each solution was placed in an incubator overnight. After this period, the remaining extracts were obtained from the stock solution $(10 \mathrm{mg} / \mathrm{mL})$ by serial dilution to the following concentrations: $0.1 \mathrm{mg} / \mathrm{mL}$ and $1 \mathrm{mg} / \mathrm{mL}$.

\section{Cytotoxicity Test}

Cell Culture

An MTT (3-(4,5-dimethylthiazol-2-yl)-2,5diphenyltetrazolium bromide) test was performed as described by Mosmann (14). Briefly, NIH-3T3 fibroblasts (American Type Culture Collection - ATCC - mouse embryonic cell lineage) were cultivated in DMEM 10\% FBS, with $1 \%$ penicillin/streptomycin. Cells were plated at a density of $1.6 \times 10^{3}$ per well in 96-well plates (TPP ${ }^{\circledast}$, Trasadingen, Switzerland) and then incubated at $37{ }^{\circ} \mathrm{C}$ and $5 \% \mathrm{CO}_{2}$. After $12 \mathrm{~h}$, adherent cells were treated with different concentrations of extracts prepared with the cement diluted in DMEM 10\% FBS, according to International Organization for Standardization (ISO) standard 10993-5 (15). Untreated cells (control group) were maintained in DMEM 10\% FBS.

\section{MTT Assay}

Cells were plated and treated as described above for 12,24 , and $48 \mathrm{~h}$. After each period, the medium, per well, was removed and new medium (no serum) was added, followed by the addition of $20 \mu \mathrm{L}$ of $\mathrm{MT}(0.5 \mathrm{mg} / \mathrm{mL}$ in PBS - phosphate-buffered saline), and incubated for $4 \mathrm{~h}$ at $37^{\circ} \mathrm{C}$. Formazan precipitate was solubilized with 100 $\mu \mathrm{L} /$ well of isopropyl alcohol. Assays were performed in triplicate. The plates were read in a spectrophotometer (FLUOstar OPTIMA, BMG Labtech, Offenburg, Germany) at $540 \mathrm{~nm}$.

\section{Crystal Violet Assay}

Cells were plated and treated as described above for 12 , 24 , and $48 \mathrm{~h}$. After each period, the medium was removed and the cells were washed with PBS and placed in absolute ethanol and glacial acetic acid $(3: 1, \mathrm{vol} / \mathrm{vol})$ for $10 \mathrm{~min}$ at room temperature. Next, cells were stained with crystal violet $0.1 \%(\mathrm{wt} / \mathrm{vol})$ for $10 \mathrm{~min}$ at room temperature. Excess dye was washed with distilled water. The dye was extracted with 10\% acetic acid. Assays were performed in triplicate. The plates were read in a spectrophotometer (FLUOstar OPTIMA, BMG Labtech, Offenburg, Germany) at $550 \mathrm{~nm}$.

\section{Statistical Analysis}

Data are presented as mean \pm standard deviation of at least 3 independent experiments. All statistical analyses were performed with the Prism GraphPad 5.0 (Prism Software, GraphPad, San Diego, CA, USA) on a personal computer. Parametric analysis was performed by variance analysis followed by ANOVA and Tukey tests. Statistical significance was considered if $p<0.05$.

\section{Results \\ MTT Assay}

In general, with the concentration of $10 \mathrm{mg} / \mathrm{mL}$ there was an increase in viability of those groups treated with WPC and WPCZO when compared to the control group. A similar profile for the absorbance values was noted among the groups. After $12 \mathrm{~h}$ of treatment, every group treated with $10 \mathrm{mg} / \mathrm{mL}$ presented an increase in viability compared to the control group (Fig. 1). Furthermore, the other 2 concentrations of WPCZO increased the proliferation of fibroblasts after $12 \mathrm{~h}$ of treatment. It was noted that MTA $10 \mathrm{mg} / \mathrm{mL}$ didn't cause an increase in proliferation after $24 \mathrm{~h}$, contrary to the 2 experimental groups of the same concentration (Fig. 1).

As in the previous period, the WPCZO also presented increasing viability at the $1 \mathrm{mg} / \mathrm{mL}$ concentration $(p<0.05)$. After $48 \mathrm{~h}$, only groups treated with WPC and WPCZO at $10 \mathrm{mg} / \mathrm{mL}$ presented an increase in viability compared to the control group (Fig. 1). On the other hand, both groups with smaller concentrations presented a decrease in viability $(p<0.05)$.

\section{Crystal Violet Stain}

After $12 \mathrm{~h}$, almost every group presented an increase in viability, except WPC at a concentration of $0.1 \mathrm{mg} / \mathrm{mL}$ (Fig. 2). In the 24-hour period, it was observed that every group at $10 \mathrm{mg} / \mathrm{mL}$ concentration (Fig. 2) presented greater viability compared to the control group $(p<0.05)$. After 48 $h$, only the WPC group at $10 \mathrm{mg} / \mathrm{mL}$ presented a statistically significant $(p<0.05)$ increase in viability. 

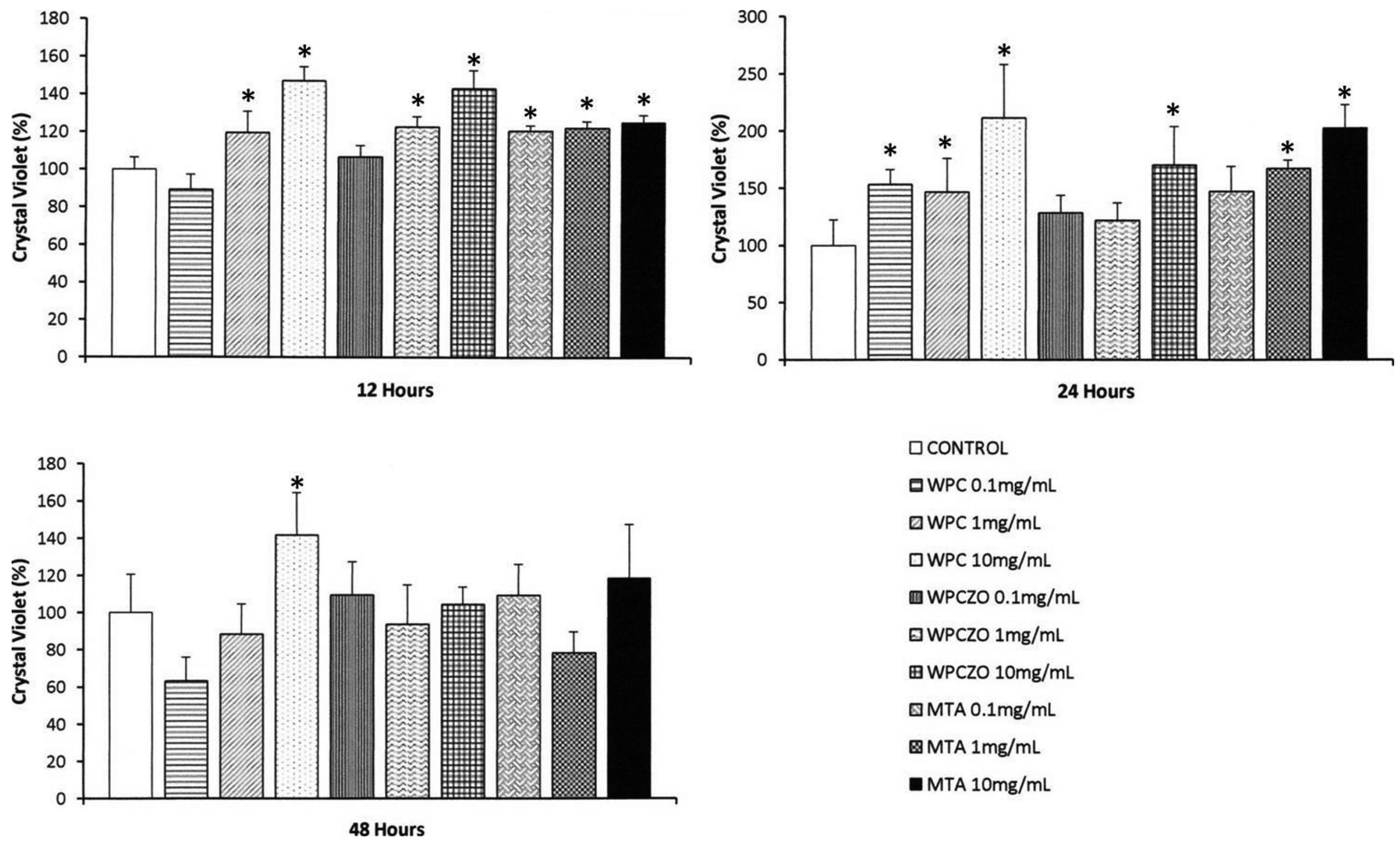

Figure 1. Viability of cells (\%) revealed by MTT when in contact for 12,24 , and $48 \mathrm{~h}$ with different concentrations ( $10 \mathrm{mg} / \mathrm{mL}, 1 \mathrm{mg} / \mathrm{mL}$, and $0.1 \mathrm{mg} /$ $\mathrm{mL}$ ) of the materials: white Portland cement (WPC), white Portland cement with zirconium oxide (WPCZO), and white MTA angelus (MTA), as well as a control group (CONTROL). Significant differences from the control group are represented by an asterisk (*; $p \leq 0.05)$.
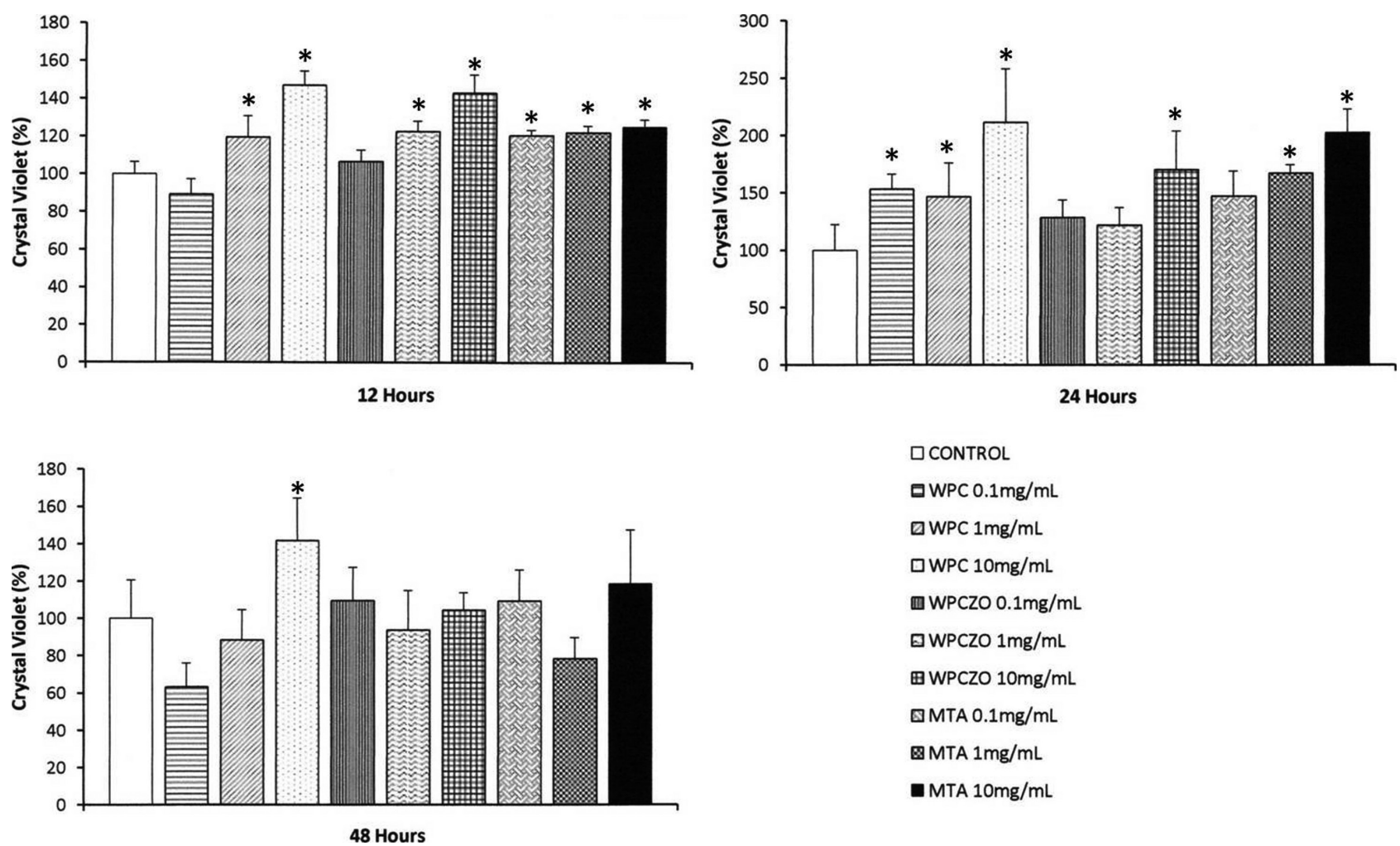

Figure 2. Viability of cells (\%) revealed by crystal violet when in contact for 12,24 , and $48 \mathrm{~h}$ with different concentrations $(10 \mathrm{mg} / \mathrm{mL}, 1 \mathrm{mg} / \mathrm{mL}$ and $0.1 \mathrm{mg} / \mathrm{mL}$ ) of the materials: white Portland cement (WPC), white Portland cement with zirconium oxide (WPCZ0), and white MTA Angelus (MTA), as well as a control group (CONTROL). Significant differences from the control group are represented by an asterisk $\left({ }^{*} ; p \leq 0.05\right)$. 


\section{Discussion}

Biological compatibility is one of the most important properties of endodontic materials. The final result of endodontic treatment depends on the tissue response to these materials (16). This study evaluated the effect of the addition of zirconium oxide on the cytotoxicity of experimental calcium silicate-based cement. In this study, cell viability was determined by MTT assay, based on the capacity of mitochondrial enzymes in living cells to convert salt MTT (yellow) to formazan crystals (dark blue), and by using crystal violet, which is a test based on the ability of DNA from viable cells to capture the pigment (gentian violet).

The in vitro tests employing cell culture are advantageous due to their simplicity, quickness, low costs (17), reproduction in reduced time, and the increased control they offer over the experimental conditions $(\mathrm{pH}$ maintenance, $\mathrm{CO}_{2}$ concentration, and levels of signaling molecules) (18). Furthermore, in vitro models can reduce or eliminate the use of animals and the associated ethical implications (18).

On the other hand, in vitro viability tests (MT, crystal violet, and neutral red) have some limitations, including the impossibility of keeping the cells alive after the procedure and the inability to quantify and detect the type of cell death (17). Actually, these tests can give a specific idea of the viability, cellular proliferation, and metabolism compared to a control group. This information (viability, proliferation, and metabolism) is important to show what the behavior of a cell is after an experimental protocol. We used 10\% FBS for all groups because this condition can maintain cellular proliferation/viability and allow comparison between control and experimental groups, especially with the MTT assay (14).

Studies examining biocompatibility, genotoxicity, and arsenic release showed similar results between MTA and $\operatorname{WPC}(4,5,7,10)$, corroborating the findings of this study on cultured fibroblasts.

Zirconium oxide has been studied by many authors, including our research group (19), and the results are promising because of its ability to maintain physical, chemical, and biological properties (20). In this context, the present study generated results that support its application, revealing the cytotoxicity of WPCZO as similar to the control group.

The present results showed the high concentration of material $(10 \mathrm{mg} / \mathrm{mL})$ in all groups caused an increase in viability, particularly after 12 and $24 \mathrm{~h}$. By comparison, another study (20) showed MTA and WPC caused an increase in viability after 12 and $24 \mathrm{~h}$. The same study also showed that, after 48 and $72 \mathrm{~h}$, the WPC groups treated with different concentrations of bismuth oxide presented higher viability than the MTA and untreated WPC groups. Our results were similar for some groups with the highest concentration, although viability decreased at lower concentrations.

The 24-h MT results were consistent with the literature, showing MTA did not inhibit cell viability and showing no difference from the control group (21).

Other studies showed WPC has no cytotoxic behavior and exhibits cell viability similar to that of the control group $(5,22)$. Our results revealed that, even in some concentrations ( 1 and $10 \mathrm{mg} / \mathrm{mL}$ ), WPC did not reduce cell proliferation when compared to the control group, in accordance with previous reports $(5,22)$. Other authors have also shown lower in vitro cytotoxicity of MTA and WPC for various cell types, such as mesenchymal stem cells, osteosarcoma cell lines, osteoblasts, and gingival fibroblasts (21-24).

Zirconium oxide, as other radiopacifiers, has shown no genotoxicity when evaluated on murine osteoblasts, probably indicating this element may not present a cytotoxic behavior (13). Compared to that study, the WPCZO showed no toxic effect either; in fact, at some concentrations ( 10 and $1 \mathrm{mg} / \mathrm{mL}$ ) and a period of $24 \mathrm{~h}$, it caused an increase in viability. WPC treatment resulted in an increase in cellular viability, and we speculate this could be due to some specific alteration in cell-signaling pathways, as some authors have already reported such alterations in those mechanisms as a result of increased cell viability (21-25).

Some molecular mechanisms of the action of cements and endodontic materials have been studied (22-25), but few questions have been addressed so far among them, the up- or down-regulation of genes related to mineralization (such as osteonectin and bone sialoprotein), flash regulatory molecules (iNOS, COX-2) (23), bone morphogenetic proteins 2 and 4 (BMP-2 and BMP-4), fibroblast growth factor 4 (FGF4) (25), and matrix metalloproteinases (24).

Regardless of the mechanism involved, this study could demonstrate that the addition of zirconium oxide does not cause changes in the biological properties of WPC and that it could be a potential radiopacifying agent for WPC.

Zirconium oxide may be an alternative radiopacifying material for root-end filling, and the white coloration of the material offers favorable esthetics if used as a pulpcapping material.

\section{Resumo}

0 objetivo deste estudo foi verificar se o uso do óxido de zircônia como radiopacificador de um cimento experimental à base de silicato de cálcio (WPCZO) levou a citotoxicidade. Os fibroblastos foram tratados com diferentes concentrações (10 mg/mL, $1 \mathrm{mg} / \mathrm{mL}$ e $0,1 \mathrm{mg} / \mathrm{mL})$ dos cimento diluídos em meio Eagle modificado por Dulbecco (DMEM) durante períodos de 12, 24, e 48 horas. Os grupos testados foram: cimento 
Portland (WPC), cimento Portland branco com óxido de zircônio (WPCZ0) e MTA Angelus branco (MTA). No grupo controle as células não foram tratadas. A citotoxicidade foi avaliada por meio da mitocondrial-atividade (MTT) e ensaio de densidade celular (cristal violeta). Todos os cimentos apresentaram baixa citotoxicidade. Em geral, na concentração de $10 \mathrm{mg} /$ $\mathrm{mL}$, houve um aumento na viabilidade desses grupos tratados com WPC e WPCZO quando comparado com o grupo controle $(p<0,05)$. Um perfil semelhante para os valores de absorvância foi observado entre os grupos: $10 \mathrm{mg} / \mathrm{mL}$ apresentaram um aumento da viabilidade em relação ao grupo controle. Por outro lado, as concentrações menores apresentaram uma viabilidade semelhante ou inferior em comparação com o grupo controle, em geral. Um novo material odontológico composto de cimento à base de silicato de cálcio com 20\% de óxido de zircônio, como o radiopacificador, apresentou baixa citotoxicidade e pode ser explorado como um material promissor para retrobturações.

\section{Acknowledgements}

The authors thank Prof. Dr. Vinícius Carvalho Porto, head of the Centro Integrado de Pesquisa laboratories (Bauru Dental School - USP). The first author was a recipient of a fellowship from FAPESP (Process \# 2009/11585-4).

\section{References}

1. Shah PM, Chong BS, Sidhu SK, Pitt Ford TR. Radiopacity of potential root-end filling materials. Oral Surgery 1996;81:476-479.

2. Torabinejad M, Hong CU, Pitt Ford TR, Kettering JD. Antibacterial effects of some root end filling materials. J Endod 1995;21:403-406.

3. Zeferino EG, Bueno CES, Oyama LM, Ribeiro DA. Ex vivo assessment of genotoxicity and cytotoxicity in murine fibroblasts exposed to white MTA or white Portland cement with 15\% bismuth oxide. Int Endod J 2010;43:843-848.

4. Holland R, Souza V, Nery MJ, Faraco Junior IM, Bernabe PF, Otoboni Filho JA, et al.. Reaction of rat connective tissue to implanted dentin tube filled with mineral trioxide aggregate, Portland cement or calcium hydroxide. Braz Dent J 2001;12:3-8.

5. Saidon J, He J, Zhu Q, Safavi K, Spangberg LS. Cell and tissue reactions to mineral trioxide aggregate and Portland cement. Oral Surg Oral Med Oral Pathol Oral Radiol Endod 2003;95:483-489.

6. Danesh G, Dammaschke T, Gerth HU, Zandbiglari T, Schäfer E. A comparative study of selected properties of ProRoot mineral trioxide aggregate and two Portland cements. Int Endod J 2006;39:213-219.

7. Ribeiro DA, Sugui $M M$, Matsumoto $M A$, Duarte $M A$, Marques $M E$, Salvadori DM. Genotoxicity and cytotoxicity of mineral trioxide aggregate and regular and White Portland cements on Chinese hamster ovary (CHO) cells in vitro. Oral Surg Oral Med Oral Pathol Oral Radiol Endod 2006;101:258-261.

8. Hungaro Duarte MA, Oliveira El, Kadre GD, Vivan RR, Guerreiro Tanomaru JM, et al.. Radiopacity of Portland cement associated with different radiopacifying agents. J Endod 2009;35:737-740.

9. Belobrov I, Parashos P. Treatment of tooth discoloration after the use of white mineral trioxide aggregate. J Endod 2011;37:1017-1020.

10. Duarte MA, Oliveira Demarchi AC, Yamashita JC, Kuga MC, Campos Fraga S. Arsenic release provided by MTA and Portland cement. Oral
Surg Oral Med Oral Pathol Oral Radiol Endod 2005;99:648-650.

11. Camilleri J, Montesin FE, Papaioannou S, McDonald F, Pitt Ford TR. Biocompatibility of two commercial forms of mineral trioxide aggregate. Int Endod J 2004;37:699-704.

12. Ribeiro DA, Carlin V, Fracalossi AC, Oyama LM. Radiopacifiers do not induce genetic damage in murine fibroblasts: an in vitro study. Int Endod J. 2009; 42:987-991.

13. Camilleri J. Characterization of hydration products of mineral trioxide aggregate. Int Endod J 2008;41:408-417.

14. Mosmann T. Rapid colorimetric assay for cellular growth and survival: application to proliferation and cytotoxicity assays. Journal of Immunological Methods 1983;65:55-63.

15. International Standards Organization (ISO) (2009) ISO 109935:2009. Biological evaluation of medical devices - Part 5: Tests for in vitro cytotoxicity. International Standards Organization, Geneva, Switzerland.

16. Camilleri J, Cutajar A, Mallia B. Hydration characteristics of zirconium oxide replaced Portland cement for use as a root-end filling material. Dental Materials 2011;27:845-854.

17. Freshney RI. Culture of animal cells: a manual of basic techniques. 5th ed. New York: Wiley-Liss; 2005.

18. Schweikl H, Schmalz G. Toxicity parameters for cytotoxicity testing of dental materials in two different mammalian cell lines. Eur J Oral Sci 1996;104:292-299

19. Viapiana R, Flumignan DL, Guerreiro-Tanomaru JM, Camilleri J, Tanomaru-Filho M. Physicochemical and mechanical properties of zirconium oxide and niobium oxide modified Portland cement-based experimental endodontic sealers. Int Endod J 2014;47:437-448.

20. Kim EC, Lee BC, Chang HS, Lee W, Hong CU, Min KS. Evaluation of the radiopacity and cytotoxity of Portland cements containing bismuth oxide. Oral Surg Oral Med Oral Pathol Oral Radiol Endod 2008;105:e5457

21. Gomes-Filho JE, Watanabe $\mathrm{S}$, Gomes AC, Faria MD, Lodi CS, Oliveira SHP. Evaluation of the Effects of Endodontic Materials on Fibroblasts Viability and Cytokine Production. J Endod 2009;35:1577-1579.

22. Al Anezi AZ, Zhu Q, Wang YH, Safavi KE, Jiang J. Effect of selected accelerants on setting time and biocompatibility of mineral trioxide aggregate (MTA). Oral Surg Oral Med Oral Pathol Oral Radiol Endod 2011;111:122-127.

23. Kim TG, Lee YH, Bhattari G, Lee NH, Lee KW, Yi HK, et al. . PPAR inhibits inflammation and RANKL expression in epoxy resin-based sealerinduced osteoblast precursor cells E1 cells. Arch Oral Biol 2013;58:2834.

24. Silva EJ, Accorsi-Mendonça T, Almeida JF, Ferraz CC, Gomes BP, Zaia AA. Evaluation of cytotoxicity and up-regulation of gelatinases in human fibroblast cells by four root canal sealers. Int Endod J 2012;45:49-56.

25. Asgary S, Nazarian H, Khojasteh A, Shokouhinejad N. Gene expression and cytokine release during odontogenic differentiation of human dental pulp stem cells induced by 2 endodontic biomaterials. J Endod 2014;40:387-392. 